
ДЖЕРЕЛ ВІДНОВЛЮВАЛЬНОЇ ЕНЕРГІЇ

\author{
${ }^{1)}$ Родіонов В. С., ${ }^{2)}$ Сорока С. О., ${ }^{3)}$ Родіонов С. В. \\ 1) Державна установа "Інститут геохімії навколишнього середовища Національної академії \\ наук Украӥни", Відділ ядерно-фізичних технологій, Київ, Украӥна \\ ${ }^{2)}$ Національний технічний університет Украӥни "Київський політехнічний інститут імені \\ Ігоря Сікорського", Київ, Украӥна \\ ${ }^{3)}$ Національний університет харчових технологій, Київ, Украӥна \\ E-mail:sso-ua@ukr.net
}

В роботі розглянуто технології отримання активних елементів для літій-іонних акумуляторів на основі напилення плівки графіту і нанесення на неї шару оксиду олова. Отриманий результат, при використанні плів$\kappa и ~ \mathrm{SnO}_{2}$, показує, шуо параметри незворотної ємності можуть перевищувати значення зворотної ємності, шзо отримуються просто на чистому графіті (300-350 mАгод/гр). Це показує перспективність створення активного анода зі структурою графіт-оксид олова. В роботі висвітлено напрямки оптимізації технологічних процесів отримання плівок, важливість правильного підбору співвідношень товщини, а також можливості переходу до нанесення на вуглецеву структуру оксиду олова.

На відміну від загально прийнятої технологї нами здійснювалося отримання анодної системи електрода літій-іонного акумулятора (ЛІА) за допомогою вакуумного напилення на мідну фольгу, на який методом високочастотного магнетронного осадження наносилися шар графіту і олова з дотриманням низки технологічних вимог.

Отримана нами на структурах графіт-оксид олова має надзвичайно великий розкид значень від 380 mАгод/гр до 690 mАгод/гр. Ймовірно це пов'язано з невідпрацьованою технологією отримання графіту олова методом окислення, оскільки в результаті виходять багатофазні включення оксиду олова. Неоднозначність структури графіту залежно від товщини плівки також впливає на результат.

3 представлених результатів слідує, щуо ведеться інтенсивний пошук альтернативних вуглецю матеріалів для анода літій-іонного акумулятора. І хоча в даний час жоден з досліджених матеріалів за сукупністю свойх характеристик не може конкурувати з вуглецем, можна сподіватися, що композити та нанокомпозити з вуглецю і невуглецевих матеріалів знайдуть найближчим часом застосування у виробництві ЛІА.

На основі отриманих результатів показано можливість вдосконалення технічних рішень та впровадження у виробництво літій-іонних акумуляторів нових технологічних процесів, а також проаналізовано можливі напрямки покращення їхніх експлуатаційних характеристик.

Ключові слова: графіт; електрод; оксид олова; літій-іонний; наноплівка.

\section{Вступ}

Оксид олова - одна 3 метало-оксидних сполук, що відносяться до класу матеріалів, які мають міжнародне позначення як TCO (Transhfrent conductive oxides) [1, 2], тобто є матеріалами, котрі виявляють такі фізичні властивості, як висока оптична прозорість і велика електрична провідність $[2,3]$.

Саме ці матеріали стали передумовою до створення так званої прозорої електроніки $[4,5,6]$

До групи традиційних ТСО відносяться такі матеріали, як $\mathrm{In}_{2} \mathrm{O}_{3}, \mathrm{ZnO}, \mathrm{CdO}, \mathrm{TiO}_{2}, \mathrm{SnO}_{2}$. Ці матеріали знайшли широке застосування в електронній техніці, оптоелектроніці і мікроелектроніці, газоаналізаторах, світлодіодних і електролюмінісцентних структурах, сонячних батареях, каталізаторах [7-10].

Одним $з$ технічних напрямків, які в останні два десятиліття розвиваються бурхливими темпа- ми, є розробка і випуск літій-іонних акумуляторів, що призвело до переорієнтування багатьох автомобільних компаній на випуск електромобілів. Крім масового випуску електромобілів виникла велика кількість інших засобів пересування з літійіонними акумуляторами, від гіробордів до гіроскутерів, електросамокатів, електромотоциклів і електровелосипедів, а також електролітаків. Зростання світового виробництва електромобілів вражає, а саме, якщо в 2017 році було випущено 3 мільйони, то до 2030 року очікується 125-150 мільйонів. Це зростання вимагає від розробників літій-іонних батарей ще більшими темпами вирішувати питання поліпшення параметрів джерел живлення автомобілів.

Практично всі випущені в даний час серійно літій-іонні акумулятори (ЛІА) мають негативні електроди виготовлені 3 вуглецевих матеріалів. Незважаючи на очевидний комерційний успіх ЛІА, 
все ж потрібно підвищити кількість енергії, що запасається в ЛІА, підвищивши надійність їх роботи.

Основні проблеми вдосконалення негативних електродів зводяться до підвищення інтеркаляційної (зворотної) ємності і до зниження незворотної ємності. Анод на основі графіту, який є основним матеріалом негативного електрода ЛІА [11], має теоретичну ємність $372 \mathrm{~m}$ Агод/гр. Хоча реально ця ємність і досягається в 300-350 тАгод/гр [12] i не може задовольнити очікування електромобілебудування .

У графітових матеріалах на шість атомів вуглецю доводиться не більше одного атома літію $\mathrm{LiC}_{6}$, чому i відповідає питома ємність 272 mАгод/гр. Однак в реальному випадку $є$ й інші метастабільні стани інтеркаляції літію, а саме, це $\mathrm{LiC}_{12} \mathrm{i} \mathrm{LiC}_{18}$ [13], що і знижує ємність графітового анода [14].

У зв'язку з цим розробники шукають нові комбіновані матеріали з метою підвищення ємності. Так літій, олово, алюміній, кремній мають теоретичну ємність відповідно 3860 мАгод/гр, 959 mАгод/гр, 2235 mАгод/гр, 4211 mАгод/гр. Однак використання цих матеріалів, які природно зацікавили розробників, на жаль має місце (у випадку з літієм) зростання дендритів при процесах заряду, які внаслідок замикання катода і анода руйнують структуру ЛІА. Подібний ефект спостерігається 3 алюмінієм [13] .

Новим етапом розвитку концепції анодного електрода ЛІА $\epsilon$ роботи японської компанії Fujifilm Ceiltee, яка створила композитний електрод на основі оксиду олова [15]. Хоча в результаті ïх дослідження з'явилися рекордні значення ємності 990 тАгод/гр., проти 372 мАгод/гр існуючих до тепер вуглецевих анодів. До теперішнього часу дані композитні аноди на основі $\mathrm{SnO}_{2}$ промисловістю не освоєні.

Незважаючи на отриманий результат, японські розробники показали перспективний напрямок для подальших робіт.

\section{Результати дослідження}

Нами досліджувалася наступна структура тонкоплівкового анода: нанорозмірний шар графіту, товщиною близько 100 нм, нанесений на мідну фольгу магнетронним напиленням, на який тим же методом нанесено шар олова порядку 1-15 нм, який в подальшому піддавався окисленню.

Для визначення якості структурної недосконалості плівки вуглецю, були виміряні спектри комбінаційного розсіювання світла (КРС). Аналіз цих спектрів показав наявність плівки вуглецю на підкладці (рис. 1).

Відомо, що спектроскопія комбінованого розсіювання $\epsilon$ ефективним методом дослідження структури і якості вуглецевих зразків. Характерні особливості спектрів КРС вуглецевих сполук про- являються в області частот коливань першого порядку (1000-1800 $\left.\mathrm{cm}^{-1}\right)$ і другого порядку (2400$\left.3200 \mathrm{~cm}^{-1}\right)$.

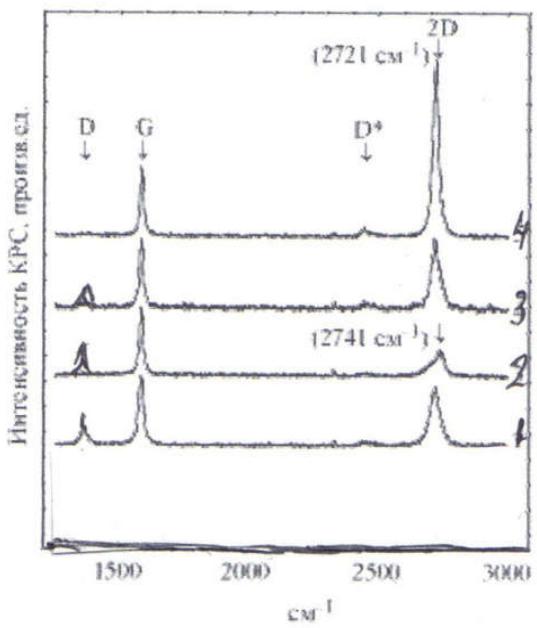

Рис. 1. Аналіз спектрів тонкоплівкового анода

Структура вуглецевого з'єднання по лінії ВРХ може значно розширюватись і звужуватись по частоті.

В області частот першого порядку зазвичай присутні дві смуги $\left(1350 \mathrm{~cm}^{-1}\right)$ i $\left(1590 \mathrm{~cm}^{-1}\right)$, які позначаються як D. Важливою особливістю смуги D $\epsilon$ те, що іiі інтенсивність корелюється зі ступенем розвпорядкованості кристалічної структури вуглецевих зразків. Для зразків з високою кристалічною досконалістю інтенсивність смуги D прямує до нуля.

На рис. 1 наведені смуги вуглецевої плівки, нанесеної на металеву фольгу. Ступінь їх кристалічної впорядкованості залежить від режимів технологічного процесу і товщини плівки, що наноситься. Зі збільшенням товщини плівки графіту впорядкованість структури збільшується. Так спектри 1-3 вказують на значну розвпорядкованість структури і відповідають товщинам плівок 30, 20 і 60 нм відповідно. При товщині 100 нм (спектр 4) структура графіту є більш впорядкована. При нанесенні на графіт плівки олова і ії термообробці виникає складність 3 їі ідентифікацією і визначенням їі товщини. У зв'язку з цим проводилися дослідження структури вихідної плівки олова на супутніх тест-зразках на скляній підкладці (рис. 2, рис. 3).

Рентгенофазовий аналіз плівок товщиною 30 нм був виконаний методом рентгенівської дифракції на приладі Thermo ARL XTRA з використанням $\mathrm{CuKa}$-випромінювання (рис. 3). Аналіз показав наявність фаз тетрагонального олова $\mathrm{Sn}$ i $\mathrm{SnO}$ тетрагональной і орторомбічної модифікації в плівках, окислених при $200^{\circ} \mathrm{C}$. Після підйому температури окислення до $400{ }^{\circ} \mathrm{C}$ фаза металевого олова в складі плівок вже не виявляється. Плівки, окис- 
лені при $700 \mathrm{C}$, вже мають фазу $\mathrm{SnO}_{2}$ тетрагональной і орторомбічної модифікацій.

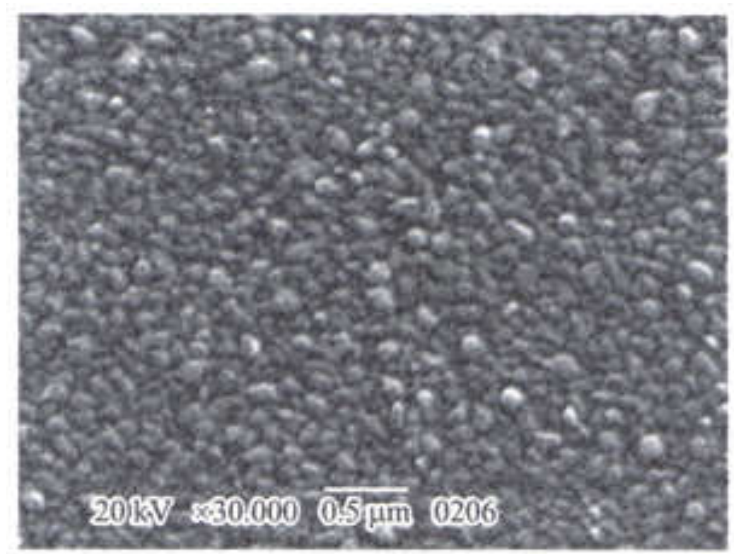

Рис. 2. Структура плівки $\mathrm{Sn}$

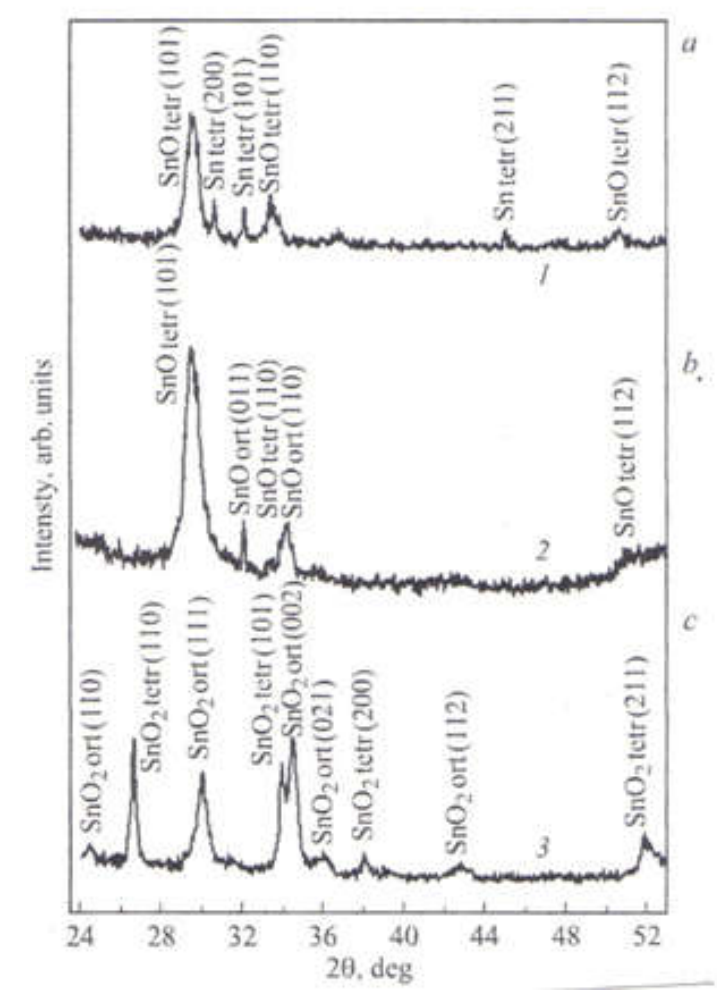

Рис. 3. Рентгенограма і фазовий склад Sn (30 нм) окислені при різній температурі, ${ }^{\circ} \mathrm{C}: 1$ - 220, 2 $-400,3-700$

Товщини досліджуваних плівок Sn задавалися часом напилення і визначалися на тестових зразках оптичним методом. Швидкість напилювання плівки склала приблизно $1 \mathrm{Hм} / \mathrm{c}$. Отримані плівки товщиною 30 нм (рис. 2) представляють собою полікристал, з розмірами кристалів 50-100 нм.

Далі проводились дослідження активної ємності структур на основі плівок графіту, отриманих магнетронним способом і «легованих» шляхом осадження олова 3 подальшм його окисленням при різних температурах: $200,400,700{ }^{\circ} \mathrm{C}$.
Отримана нами залежність на структурах графіт-оксид олова має надзвичайно великий розкид значень від 380 mАгод/гр до 690 мАгод/гр. Ймовірно це пов'язано 3 невідпрацьованою технологією отримання графіту олова методом окислення, оскільки в результаті виходять багатофазні включення оксиду олова (див. рис. 2). Неоднозначність структури графіту залежно від товщини плівки також впливає на результат.

\section{Висновки}

Незважаючи на недосконалість технології отримання активних елементів на основі напилення плівки графіту та нанесення на неї шару оксиду олова, враховуючи не оптимальне співвідношення шарів, отримані дані незворотної ємності перевищують значення зворотної ємності, що отримуються на чистому графіті (300-350 тАгод/гр). Проведені дослідження показують перспективність створення активного анода зі структурою графіт-оксид олова. Для покращення результатів слід оптимізувати технологічний процес отримання плівок, їх товщину і підбір співвідношень товщини, а також по можливості, перейти до нанесення зразу оксиду олова, а не олова, з наступною термообробкою.

\section{Література}

[1] H. L. Hartnagel, A. L. Dawar, A. K. Jain, C. Jagadish, Semiconducting transparent thin films, Institute of Psisics Pablishing, 1995, Bristol.

[2] К. Чопра, С. Дас, Тонкопленочные солнечные элементы. Москва, СССР: Мир, 1986.

[3] Dong - won Choi, Jin-Scond Park, "Highly conductive $\mathrm{SnO} 2$ thin films", Surface \& Coating Technology, v. 259, p. 238, 2014.

[4] Т. В. Семикина, В. М. Комащенко, Л. Н. Шмырева, “Оксидная электроника, как одно из направлений прозрачной электроники”, Электроника и связь. 2010, стр.20.

[5] Jogh F. Wagner, Douglas A. Keszier, Rick E. Presley, Transperent electronics, Springer Science LLC, 2008, 217 p.

[6] Satischara B. Ogale, Thin films and heterostructure for oxide electronics. Springe Science Business Media Inc., 2005, $416 \mathrm{p}$.

[7] G. Eranna, B. S. Joshi, D. P. Runthala, R. P. Gupta, "Oxide materials for development of integrated gas sensors", State Material Science, Vol. 29, p. 111-188, 2004

[8] В. Е. Родионов, Люминесиенция оксидных и сульфидных пленок. Киев, 2010.

[9] Л. К. Марков, И. П. Смирнов, А. С. Павлюченко, М. М. Кулагина,“Отражающий р-контакт на основе тонких пленок ITO для флип-чип светодиодов AlGaInN", Физика и техника полупроводников, т. 43, № 11, с. 1564-1569, 2009. 
[10] T. J. Contts, S Nassem, "High efficiency indium tin oxide/indium phosphate solar sells", Appl. Phys. Lctt., 46(2), p. 164, 2012.

[11] N. A. Kaskedikar, I. Maier, "Lithium Storage in Carbon Nano-structures", Advanced Materials, V. 21. p. 2664, 2009.

[12] M. Endo et al., "Carbon in Lithion-ion battery", Carbon, Vol. 38, p. 183, 2000.

[13] I. R. Dahn, "Suppresscon of staging in Lithiumintercalated carbon by disorder in the host", Phys
Rev. B Vol 42. p. 6424, 1990; Vol. 44. p. 9170, 1991.

[14] A. Manthiram, "Materials Challenges and Opportunities of Lithium-ion Batteries", I. Phys Chem. Lett., v. 2, p. 176, 2011

[15] Idoto at. Al, "A New concepts of Li-ion battery", I. Pawer Science, V. 276, p. 1305, 1997.

[16] L. M. Malarda, M. A. Pimentar, G. Dresselhaus, Physics Reports, 473, pp. 51-87, 2009.

УДК $541.136 ; 621.355 .9$

${ }^{1)}$ В. Е. Родионов, ${ }^{2)}$ С. А. Сорока, ${ }^{3)}$ Е. В. Родионов

${ }^{1)}$ Государственное учреждение "Институт геохимии окружающей среды Национальной академии наук Украины"", Отдел ядерно-физических технологий, Киев, Украина

${ }^{2)}$ Национальный технический университет Украины "Киевский политехнический институт имени Игоря Сикорского", Киев, Украина

${ }^{3)}$ Национальный университет пищевых технологий, Киев, Украина

НОВЕЙШИЙ ПОДХОД К ИСПОЛЬЗОВАНИЮ ПЛЕНОК ОКСИДА ОЛОВА ДЛЯ ИСТОЧНИКОВ ВОЗОБНОВЛЯЕМОЙ ЭНЕРГИИ

В работе рассмотрены технологии получения активных элементов для литий-ионных аккумуляторов на основе напыления пленки графита и нанесения на нее слоя оксида олова. Полученный результат, при использовании пленки $\mathrm{SnO}_{2}$, показывает, что параметры необратимой емкости могут превышать значения обратной емкости, получаемых просто на чистом графите (300-350 mАгод/г). Это показывает перспективность создания активного анода со структурой графит-оксид олова. В работе освещены направления оптимизации технологических процессов получения пленок, важность правильного подбора соотношений толщины, а также возможности перехода к нанесению на углеродную структуру оксида олова.

В отличие от общепринятой технологии нами осуществлялось получение анодной системы электрода литийионного аккумулятора с помощью вакуумного напыления на медную фольгу, на которую методом высокочастотного магнетронного осаждения наносились слой графита и олова, соблюдая ряд технологических требований.

Полученная нами зависимость на структурах графит-оксид олова имеет очень большой разброс значений от 380 mАгод/г до 690 mАгод/г. Вероятно это связано с неотработанной технологией получения графита олова методом окисления, так как в результате получаются многофазные включения оксида олова. Неоднозначность структуры графита в зависимости от толщины пленки также влияет на результат.

Из представленных результатов следует, что ведется интенсивный поиск альтернативных углероду материалов для анода литий-ионного аккумулятора. И хотя в настоящее время ни один из исследованных материалов по совокупности своих характеристик не может конкурировать с углеродом, можно надеяться, что композиты и нанокомпозиты из углерода и неуглеродных материалов найдут в ближайшее время применение в производстве ЛИА.

На основе полученных результатов показана возможность совершенствования технических решений и внедрение в производство литий-ионных аккумуляторов новых технологических процессов, а также проанализированы возможные направления улучшения их эксплуатационных характеристик.

Ключевые слова: графит; электрод; оксид олова; литий-ионный; нанопленка.

\author{
${ }^{1)}$ Valeriy Yevgenovich Rodionov, ${ }^{2)}$ S. Soroka, ${ }^{3)}$ Evgenii V. Rodionov \\ 1) State Institution "Institute of Environmental Geochemistry of the National Academy of Sciences of \\ Ukraine", Department of Nuclear Physical Technologies, Kyiv, Ukraine \\ ${ }^{2)}$ National Technical University of Ukraine "Igor Sikorsky Kyiv Polytechnic Institute", Kyiv, \\ Ukraine \\ ${ }^{3)}$ National University of Food Technologies, Kyiv, Ukraine
}

\title{
A NEW APPROACH TO THE USE OF TIN OXIDE FILMS FOR RENEWABLE ENERGY SOURCES
}

In this paper, the technologies of obtaining active elements for lithium-ion batteries based on sputtering of a film of graphite and applying a layer of tin oxide on it are considered. The result obtained, when using a $\mathrm{SnO}_{2}$ film, shows that the parameters of the irreversible capacitance can exceed the values of the return capacitance obtained simply on pure 
graphite (300-350 mAh / g). This shows the prospect of creating an active anode with a tin graphite oxide structure. The directions of optimization of technological processes of obtaining films, the importance of correct selection of thickness ratios, as well as the possibility of transition to the deposition of tin oxide on the carbon structure are highlighted in the work.

In contrast to conventional technology, we have been producing anode system of electrode lithium-ion battery using vacuum sputtering on copper foil, which method of high-frequency magnetron deposition applied a layer of graphite and tin, meeting a number of technological requirements.

The graphite tin oxide obtained by us has an extremely large variation of values from $380 \mathrm{mAh} / \mathrm{g}$ to $690 \mathrm{mAh} / \mathrm{g}$. This is probably due to the raw technology of producing tin graphite by oxidation, as a result of multiphase inclusions of tin oxide. The ambiguity of the graphite structure depending on the film thickness also affects the result.

From the presented results, it follows that intensive search for alternative carbon materials for the anode of lithium-ion battery is underway. Although none of the studied materials can compete with carbon at present, it is hoped that composites and nanocomposites of carbon and non-carbon materials will find application in the production of LIA in the near future.

On the basis of the obtained results the possibility of improvement of technical solutions and introduction of new technological processes in the production of lithium-ion batteries is shown, as well as possible directions of improvement of their operational characteristics are analyzed.

Keywords: graphite; electrode; tin oxide; lithium ion; nanofilm.

Надійшла до редакиії

12 листопада 2019 року

Реиензовано

21 листопада 2019 року

\title{
УДК 681.121
}

\section{ВРАХУВАННЯ УМОВ ТА ВІДМІННОСТЕЙ ПРИ КАЛІБРУВАННІ І ЗАСТОСУВАННІ ВИМІРЮВАЛЬНИХ ПЕРЕТВОРЮВАЧІВ ПРИРОДНОГО ГАЗУ}

\author{
Коробко I. В., Капітанчук Д. Ю. \\ Національний технічний університет Украӥни \\ “Київський політехнічний інститут імені Ігоря Сікорського”, Київ, Украӥна \\ E-mail: i.korobko@kpi.ua,denykep44@gmail.com
}

Підвищення точності та надійності реєстрації природного газу є нагальною проблемою сьогодення. Одним із головних факторів впливу на точність вимірювання об'єму та об'ємної витрати газофазних середовищ $\epsilon$ невідповідність умов калібрування (повірки) засобів вимірювальної техніки умовам їх застосування. Така невідповідність в першу чергу полягає у відмінності при калібруванні і застосуванні приладу густини, температури, тиску вимірюваного середовища, щчо призводить до значних величин невизначеності результатів вимірювання. Проблема викликана відсутністю необхідного метрологічного обладнання для проведення напівнатурного калібрування.

Для розв'язання окресленої проблеми пропонується застосувати гідрогазодинамічну теорію подібності $i$ на підтрунті якої визначати комплексний критерій подібності. Такий критерій базується на числах Рейнольдса, Струхаля та Ейлера. Після проведення калібрування на повітрі, як правило за атмосферного тиску, визначається комплексний критерій, який слугує основою для розрахунку градуювальної характеристики приладу за реальних умов експлуатації.

Запропонований підхід дозволяє із високою точністю прогнозувати метрологічні характеристики лічильників турбінного класу для різних газових вимірюваних середовищ, базуючись на результатах калібрування на будь-якому з них, проводити оцінювання меж відповідності градуювальних характеристик лічильника турбінного класу за різних параметрів вимірюваного середовища, повірку (калібрування) лічильника турбінного класу здійснювати на повітрі при тиску, близькому до атмосферного, $і$ застосування для обліку природного газу з різними значеннями тиску. Це призводить до підвищення точності реєстрації природного газу без повірки приладів за умов експлуатації і створює можливість діагностування засобів вимірювання на повірочних стендах із використанням в якості вимірюваного середовища повітря.

Ключові слова: природний газ; повітря; калібрування; повірка; метрологічне обладнання; вимірювання. 